\title{
Composition and Thermal Structure of the Upper Troposphere and Lower Stratosphere in a Penetrating Mesoscale Convective Complex Determined by Satellite Observations and Model Simulations
}

\author{
Chunhua Shi, Wenyi Cai, and Dong Guo \\ Key Laboratory of Meteorological Disaster, Ministry of Education (KLME)/Joint International Research Laboratory of \\ Climate and Environment Change (ILCEC)/Collaborative Innovation Center on Forecast and Evaluation of Meteorological Disasters, \\ Nanjing University of Information Science and Technology, Nanjing, China
}

Correspondence should be addressed to Chunhua Shi; shi@nuist.edu.cn

Received 24 July 2017; Accepted 14 September 2017; Published 16 October 2017

Academic Editor: Lulin Xue

Copyright (c) 2017 Chunhua Shi et al. This is an open access article distributed under the Creative Commons Attribution License, which permits unrestricted use, distribution, and reproduction in any medium, provided the original work is properly cited.

\begin{abstract}
We describe here the composition and thermal structure of the upper troposphere and lower stratosphere during a penetrating mesoscale convective complex (MCC) event that occurred in southern China on 8 June 2009. Our results are based on satellite observations and Weather Research and Forecasting model simulations. Ice-rich and ozone-poor air reached as high as $17 \mathrm{~km}$. The air was $-5^{\circ} \mathrm{C}$ colder inside the mature MCC than outside at the first cold-point tropopause near $17 \mathrm{~km},-2^{\circ} \mathrm{C}$ colder inside the mature MCC than outside at the second cold-point tropopause, and $3^{\circ} \mathrm{C}$ warmer inside the mature MCC than outside between the two cold-point tropopauses. Corresponding to the temperature structure, there were two lower water vapor contents inside the MCC than outside near $17 \mathrm{~km}$ and $19 \mathrm{~km}$ while there was a higher water vapor content inside the MCC than outside near $18 \mathrm{~km}$.
\end{abstract}

\section{Introduction}

Deep convective systems are associated with severe weather and can also affect stratospheric-tropospheric exchange and the radiation balance of the Earth by changing the composition and thermal structure of the upper troposphere and lower stratosphere. This topic has attracted much recent attention with the development of satellite observations [16]. Penetrating mesoscale convective complexes (MCCs) are deep convective systems that have important effects on stratospheric-tropospheric exchange and the structure of the upper troposphere and lower stratosphere.

Most of deep convective activity occurs below the coldpoint tropopause (CPT) at $16-17 \mathrm{~km}$. Convective activity rarely penetrates the tropical tropopause layer, which is found between the lapse rate minimum at 10-12 km and the CPT [7] and is a crucial area for stratospheric-tropospheric exchange [8]. The deep convection system can significantly change the atmospheric structure of the tropical tropopause layer, increasing the height of the lapse rate minimum and lowering the height of the CPT [7]. Penetrating MCCs are larger and longer lived than thunderstorm cells and therefore have a greater effect on the chemical and thermodynamic structure of the upper troposphere and lower stratosphere [3].

Some satellites sample MCCs infrequently because of their viewing geometry, although, ultimately, the rarity of some types of sampling (particularly of tropopausepenetrating storms) is the result of the timing of satellite measurements. Most satellite-based systems are in Sunsynchronous orbits and make observations at local times before and after the time period in which tropopausepenetrating storms are most common (i.e., near the time of maximum surface temperature and highest instability). Therefore, there have been few studies of penetrating MCCs, but more studies of hurricanes in the upper troposphere and lower stratosphere $[9,10]$.

A penetrating MCC was observed on 8 June 2009 by the NASA A-Train satellite constellation, which is widely used to study the structure of the atmosphere [11-17]. The Microwave Limb Sounder Version 4 product, released in 
2015 (https://mls.jpl.nasa.gov/), has led to a great improvement in data quality in the upper troposphere and lower stratosphere $[18,19]$ and provides a good opportunity to understand the fine structure of the upper troposphere and lower stratosphere in a penetrating MCC. Satellite remote sensing and model simulation, together, can complement each other nicely to study the unique upper troposphere and lower stratosphere structure in a rare penetrating MCC.

\section{Materials and Methods}

2.1. NASA A-Train Satellite Data. The A-Train (Afternoon Constellation) is a group of satellites (GCOM-W1, Aqua, CALIPSO, CloudSat and Aura) operated by NASA and its international partners (http://atrain.nasa.gov/). The satellites are all in polar orbit and all cross the equator northward at about 1:30 p.m. local time. The near-simultaneous observations of a wide variety of parameters by these satellites can be used for a single purpose [20].

The Microwave Limb Sounder (MLS) instrument on board NASA's Earth Observation System Aura satellite measures the composition of the atmosphere, the temperature, humidity, and amount of cloud ice at a horizontal resolution of c. $150 \mathrm{~km}$. There are 10 pressure levels in the upper troposphere and lower stratosphere at 316, 261, 215, 178, 147, $121,100,83,68$, and $56 \mathrm{hPa}$.

The Atmospheric Infrared Sounder (AIRS) Level 2 standard product is derived from a combination of the AIRS product and the Advanced Microwave Sounding Unit on NASA's Aqua satellite. The horizontal resolution along the track is c. $50 \mathrm{~km}$ and the spatial resolution of the AIRSAdvanced Microwave Sounding Unit at the nadir view is $13.5 \mathrm{~km}$ (http://airs.jpl.nasa.gov/) [18]. The outgoing longwave radiation of the AIRS product was used in this study.

The Cloud-Aerosol Lidar with Orthogonal Polarization (CALIOP) instrument on NASA's CALIPSO satellite is a two-wavelength polarization-sensitive light detection and ranging instrument that provides high-resolution vertical profiles of aerosols and clouds. CALIOP uses three receiver channels: one measuring the $1064 \mathrm{~nm}$ backscattered intensity and another two measuring the orthogonally polarized components of the $532 \mathrm{~nm}$ backscattered signal. Level 2 products were used in this study [21].

The Cloud Profiling Radar (CPR) instrument on NASA's CloudSat satellite is a $94 \mathrm{GHz}$ nadir-looking radar that measures the power backscattered by clouds as a function of distance from the radar. The original requirements for the CPR instrument are sensitivity defined by a minimum detectable reflectivity factor of $-30 \mathrm{dBZ}$, along-track sampling of $2 \mathrm{~km}$, a dynamic range of $70 \mathrm{dBZ}, 500 \mathrm{~m}$ vertical resolution, and a calibration accuracy of $1.5 \mathrm{dBZ}$. The CPR Level 2 products were used in this study (http://cloudsat.atmos.colostate.edu/) [22].

2.2. Black-Body Temperature from the FY2C Satellite. Blackbody temperature (BBT) data recorded by the FY2C geostationary satellite was obtained from the National Satellite Meteorological Centre, China. The hourly data with a horizontal resolution of $0.1^{\circ}$ shows convection on a variety

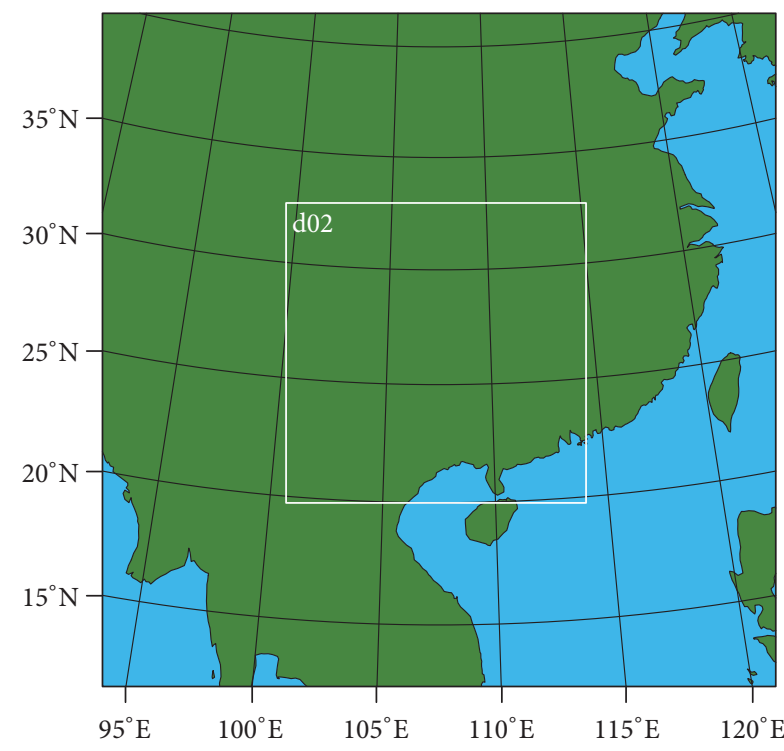

FIGURE 1: Location of study area and grids used in the MCC simulation.

of scales [23]. More details can be found at http://www .nsmc.org.cn/.

2.3. Global Positioning System Radio Occultation COSMIC Data. Global positioning system (GPS) radio occultation temperature profiles were obtained from http://cdaac-www .cosmic.ucar.edu/cdaac/products.html. Anthes et al. [24] introduced the Constellation Observing System for Meteorology, Ionosphere, and Climate (COSMIC) data. We used Level 2 wet profile data with a vertical resolution up to $100 \mathrm{~m}$.

2.4. Weather Research and Forecasting Model. The Weather Research and Forecasting model WRF-ARW V3.5.1 was used to simulate the MCC. A simulation with a time step of $60 \mathrm{~s}$ started at 00:00 GMT on 8 June 2009. The model grids were set as shown in Figure 1, with horizontal resolutions of $10 \mathrm{~km}$ inside and $30 \mathrm{~km}$ outside the MCC. Seventy vertical layers were appointed under the model top at $20 \mathrm{hPa}$. The simulation schemes included the GF cumulus convection scheme, the RRTM longwave radiation scheme, the DUDHIA longwave radiation scheme, the YSU boundary layer scheme, and the NSSL 2-mom cloud microphysics scheme (http://www2.mmm.ucar.edu/wrf/users/). A sponge layer scheme with a thickness of $5 \mathrm{~km}$ was constructed in the upper boundary layer to avoid the reflection of gravity waves. The simulation was driven by the initial conditions and boundary conditions from the Global Forecasting System with $0.5^{\circ}$ horizontal resolution.

\section{Results}

3.1. A Penetrating MCC. An MCC is convective cloud that lasts for several hours and which has a cloud top area $>50,000 \mathrm{~km}^{2}$ and a BBT lower than $-52^{\circ} \mathrm{C}$ [25]. Several strong MCCs formed over southern China in June 2009 and the MCC on 8 June 2009 was the strongest. 


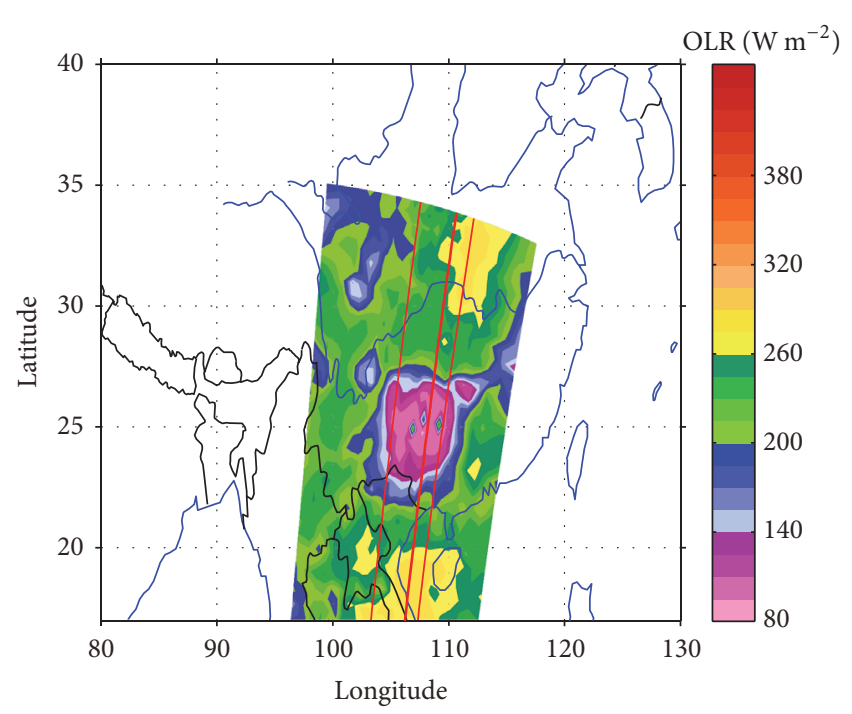

(a)

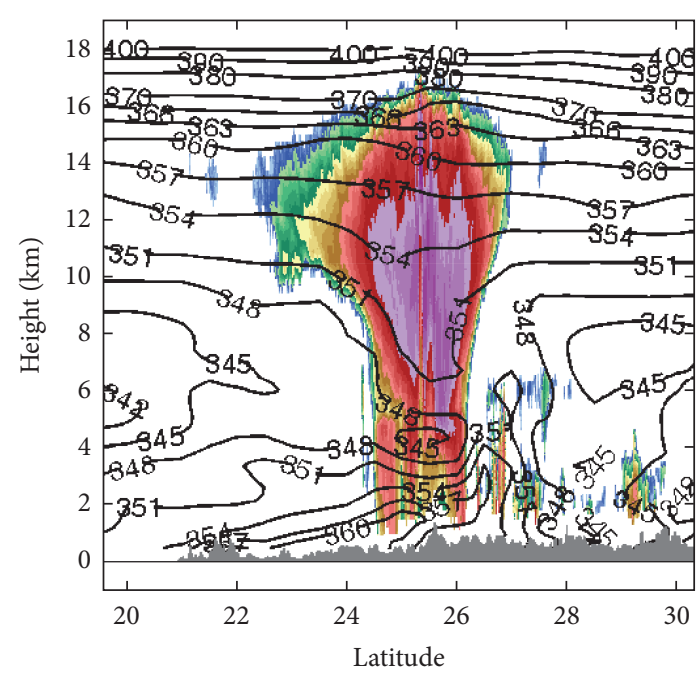

(c)

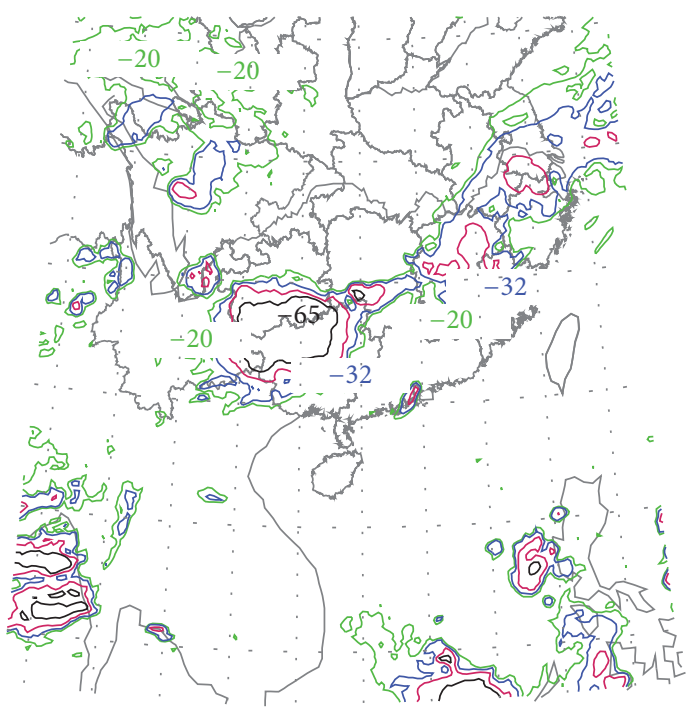

(b)
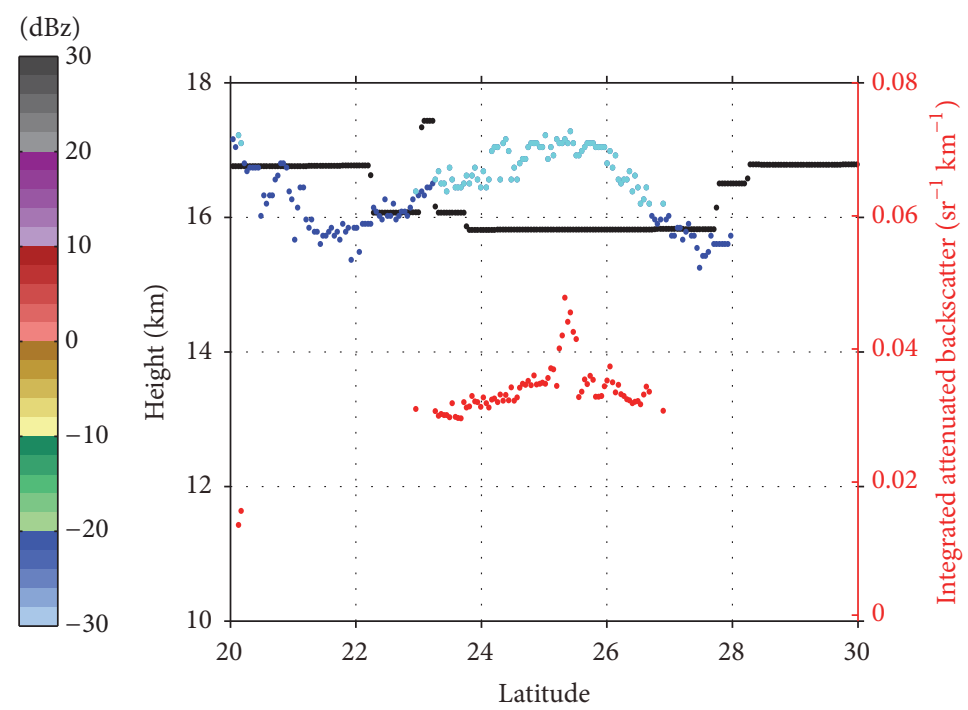

(d)

FIGURE 2: Observations from satellites at 18:00 GMT on 8 June 2009. (a) Outgoing longwave radiation $\left(\mathrm{OLR}, \mathrm{W} \cdot \mathrm{m}^{-2}\right.$ ) from the AIRS instrument (the middle thick red line is the orbit of MLS, CPR, and CALIOP instruments). (b) Black-body temperature contours from the FY2C satellite (green, blue, red, and black contours denote $-20,-32,-50$, and $-65^{\circ} \mathrm{C}$, resp.). (c) Cross-section of radar reflectivity from $\mathrm{CPR}$ (dBZ, color-shaded) and the potential pseudo equivalent temperature (K, black contours) along orbit. (d) Cross-section of data from the CALIOP instrument; left-hand $y$-axis shows the tropopause height (black dots) and the cloud top height (blue and cyan dots; cyan for overshooting cloud top) and the right-hand $y$-axis shows the integrated attenuated backscatter coefficients in the top cloud layer (red dots, $\left.\mathrm{sr}^{-1} \cdot \mathrm{km}^{-1}\right)$.

FY2C hourly BBT data (Figures 2(b), 4(a), and 4(b)) indicate that three strong MCCs (BBT less than $-65^{\circ} \mathrm{C}$ ) formed and then died out between 7 and 9 June 2009. The MCC on 8 June was a very intense feature with a large horizontal scale $(300 \mathrm{~km})$ and $>100 \mathrm{~mm}$ of cumulative rainfall.

The A-Train satellites detected this MCC at 18:00 on 8 June 2009. The outgoing longwave radiation from the AIRS instrument was $<140 \mathrm{~W} \cdot \mathrm{m}^{-2}$ in the area of the MCC (Figure 2(a)). The orbits of the satellites carrying the MLS, CPR, and CALIOP instruments passed through the MCC, allowing an analysis of the structure of the atmosphere in the area of the MCC. The CPR reflectivity can be used to represent the vertical structure of the MCC (Figure 2(c)). The central location of the MCC was near $25^{\circ} \mathrm{N}$ and $107^{\circ} \mathrm{E}$. Convective clouds developed up to $>16 \mathrm{~km}$, the cloud anvil in the upper levels extended outward, and the most intensive reflectivity $(>10 \mathrm{dBz})$ was located at $5-13 \mathrm{~km}$. The tropopause height from the ancillary meteorological data in CALIOP (Figure 2(d)) showed that the temperature lapse rate tropopause height (black dots) was almost $16 \mathrm{~km}$ in the MCC, but nearer to $17 \mathrm{~km}$ outside the MCC. The cloud top height in CALIOP 


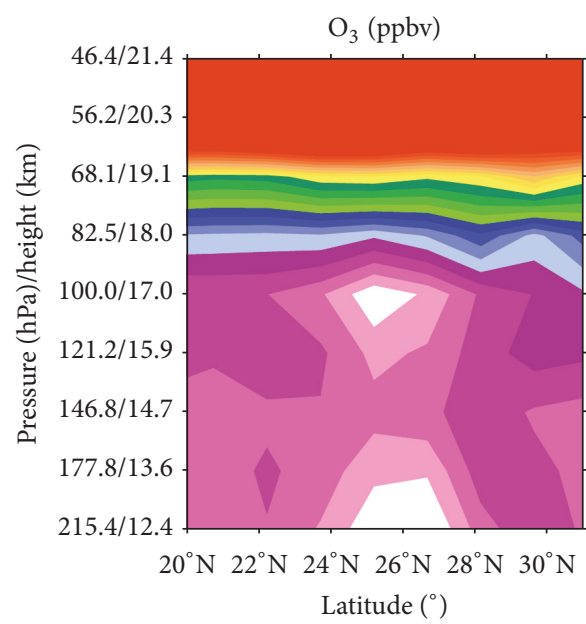

(a)

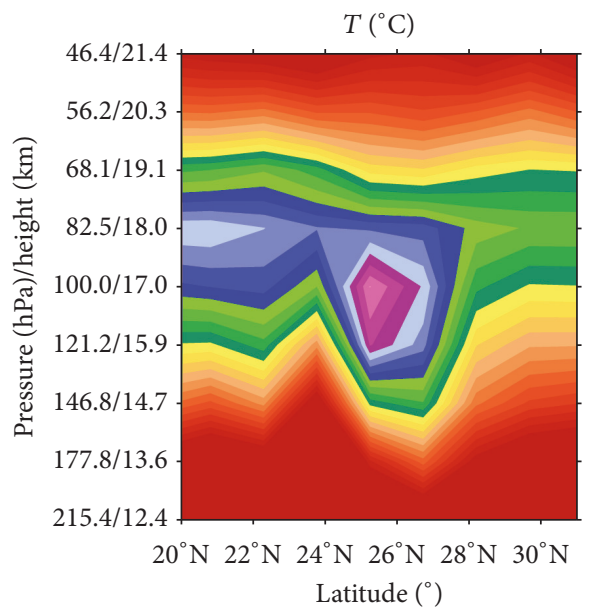

(c)

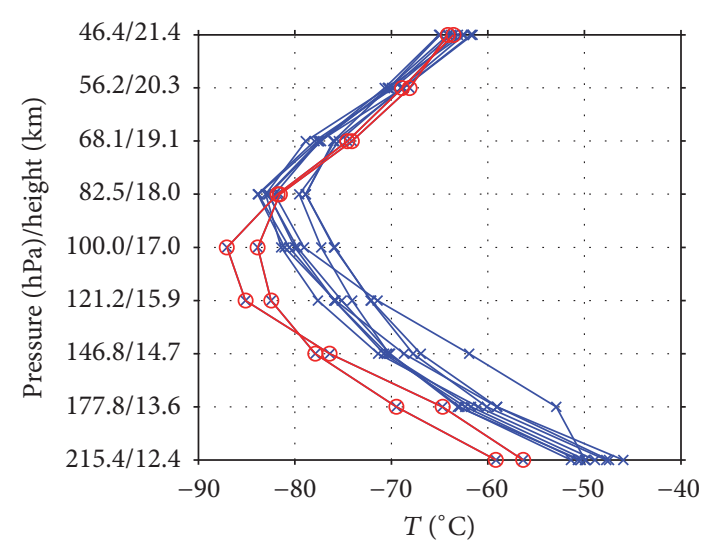

(e)

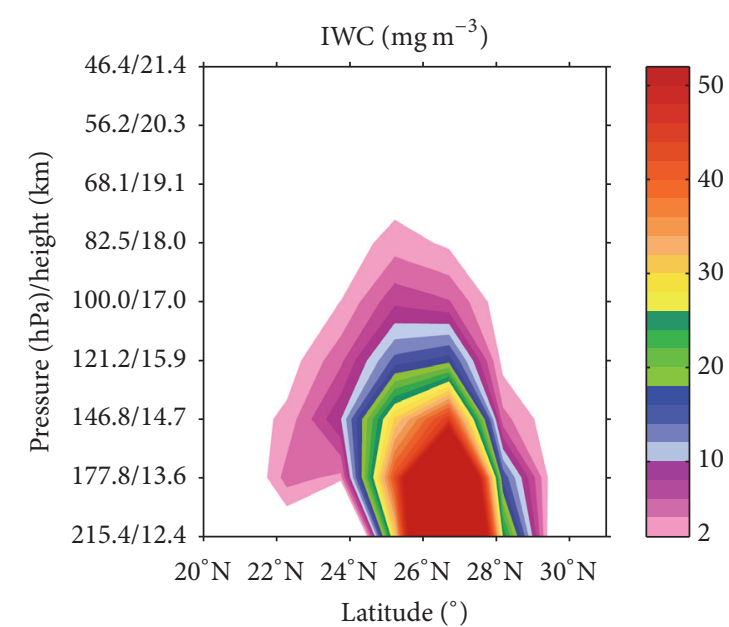

(b)

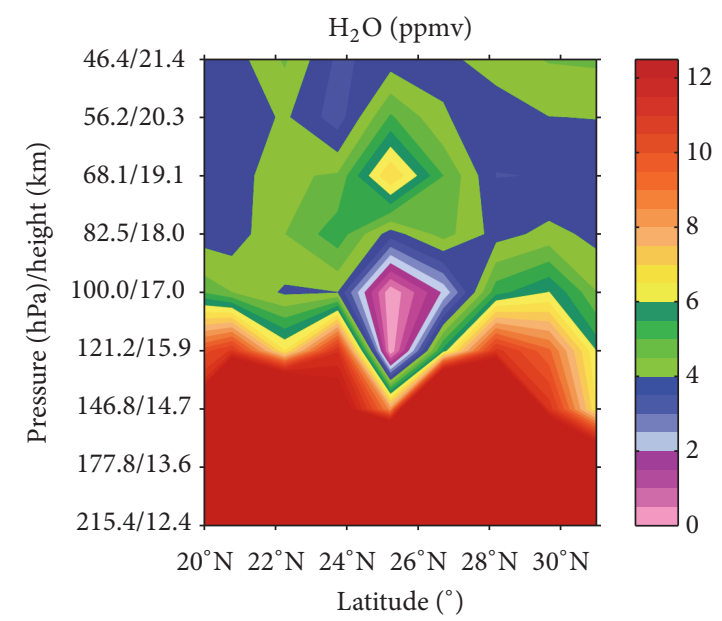

(d)

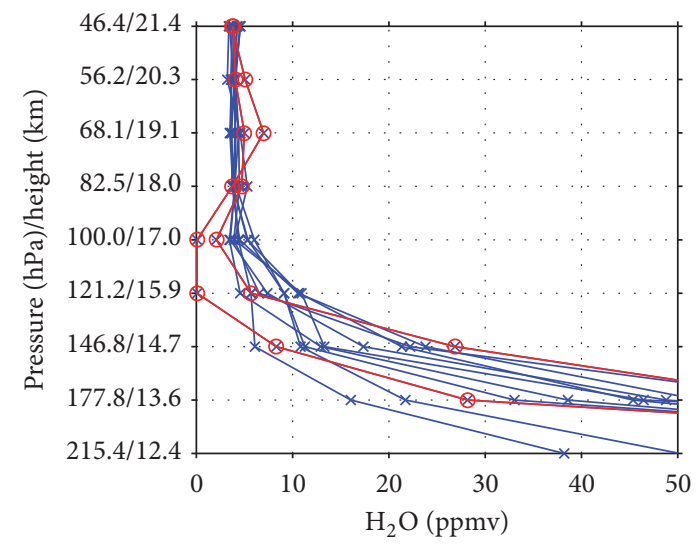

(f)

FIGURE 3: Cross-sections of the MLS results along the thick red line in Figure 2(a). (a) Ozone volume mixing ratio (ppbv); (b) IWC (mg. $\mathrm{m}^{-3}$ ); (c) temperature $\left({ }^{\circ} \mathrm{C}\right)$; (d) water vapor content (ppmv); (e) profiles of temperature inside (two red curves) and outside (eight blue curves) the MCC; and (f) profiles of water vapor content inside (two red curves) and outside (eight blue curves) the MCC. 


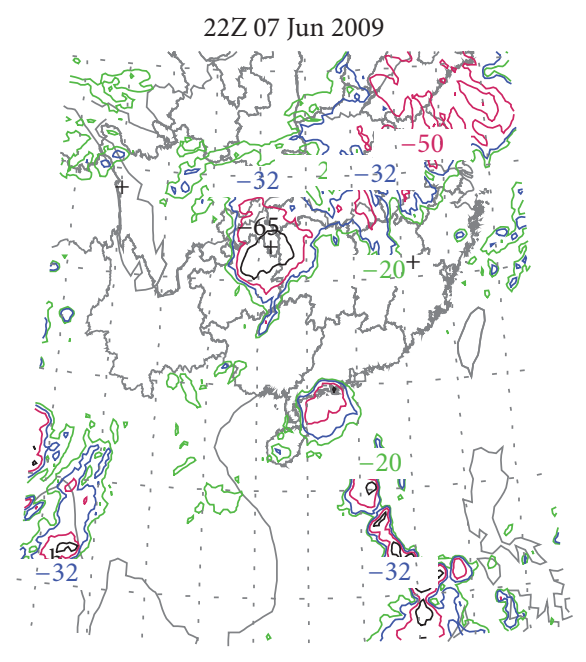

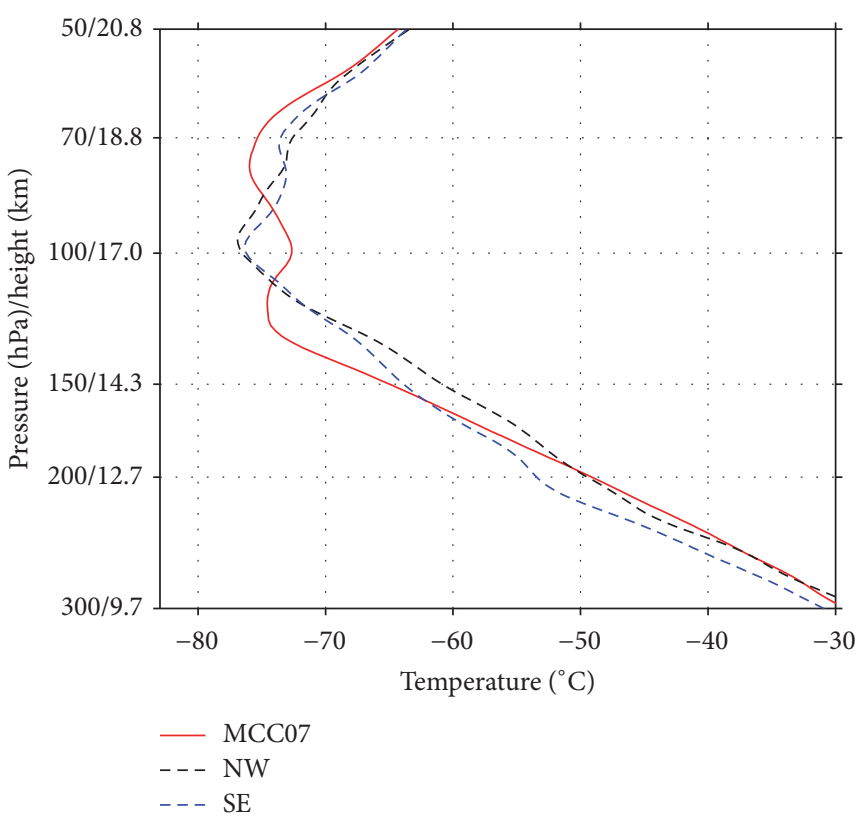

(b)

Figure 4: (a) Black-body temperature (green, blue, red, and black contours denote $-20,-32,-50$, and $-65^{\circ} \mathrm{C}$, resp.) from the FY2C satellite on 7 June 2009; + symbols indicate locations inside and outside the MCC at $15 \mathrm{~km}$ from the GPS radio occultation temperature profiles. (b) GPS radio occultation temperature profiles on 7 June 2009 inside (red curves) and outside (blue in southeast and black in northwest) the MCC.

was $>17 \mathrm{~km}$ inside the MCC (cyan dots, where the integrated attenuated backscatter coefficient of the top cloud was $>0.01 \mathrm{sr}^{-1} \cdot \mathrm{km}^{-1}$ according to Dessler [11] and Pan and Munchak [26]), that is, higher than that outside (blue dots). The red dots indicate a large concentration of particles in the cloud top; the integrated attenuated backscatter coefficients of the top clouds in the MCC were generally c. $0.03 \mathrm{sr}^{-1} \cdot \mathrm{km}^{-1}$ larger than the background value of $0.01 \mathrm{sr}^{-1} \cdot \mathrm{km}^{-1}$. The cloud was therefore a penetrating MCC.

\subsection{Upper Troposphere and Lower Stratosphere Atmospheric} Structure in the MCC from Satellite Observations. Penetrating MCCs have a large effect on the structure of the upper troposphere and lower stratosphere, including the distribution of ozone $\left(\mathrm{O}_{3}\right)$, the ice water content (IWC), and the temperature and the amount of water vapor $\left(\mathrm{H}_{2} \mathrm{O}\right)$.

The concentration of $\mathrm{O}_{3}$ and the IWC is strongly affected by upward motion in the area of the MCC. The cloud convection system can decrease the amount of $\mathrm{O}_{3}$ at lower atmospheric levels via the transport of $\mathrm{O}_{3}$-poor air upward into the upper troposphere and lower stratosphere because ozone concentrations are significantly higher in the stratosphere than in the troposphere. The concentration of $\mathrm{O}_{3}$ in the area of the MCC was $<100$ ppbv below $100 \mathrm{hPa}$. However, the concentration of $\mathrm{O}_{3}$ outside the MCC was significantly $>100$ ppbv (Figure 3(a)). The missing value somewhere inside the MCC is based on the data reliability of ozone from MLS.

By contrast, air with a high IWC of $50 \mathrm{mg} \cdot \mathrm{m}^{-3}$ was transported upward to $14 \mathrm{~km}$ and air with an IWC of $10 \mathrm{mg} \cdot \mathrm{m}^{-3}$ was transported up to $16.5 \mathrm{~km}$ within the MCC (Figure 3(b)).
The temperature profile of the MLS (Figures 3(c) and $3(\mathrm{e})$ ) shows a cold center (lower than $-85^{\circ} \mathrm{C}$ ) in the MCC at $17 \mathrm{~km}$ corresponding to the cloud top (Figure 2(d)). However, there was a warm anomaly at $2 \mathrm{~km}$ above the cold center, which is a typical characteristic of an MCC cloud top [10]. The cloud top temperature in the MCC was $2-6^{\circ} \mathrm{C}$ lower than the temperature at the same level outside the MCC. The temperature inside the MCC was $2-3^{\circ} \mathrm{C}$ warmer than outside at $2 \mathrm{~km}$ above the first CPT.

The GPS radio occultation temperature profiles with a high vertical resolution support the MLS data. GPS radio occultation only detected the MCCs on 7 and 9 June 2009. The two temperature profiles are similar. Hence we used the 7 June 2009 MCC data (Figure 4(a)) as a reference for the MCC on 8 June 2009. When the 7 June 2009 MCC occurred, the first CPT dropped from 17 to nearly $16 \mathrm{~km}$ (Figure 4(b)). The temperatures inside the MCC at the first and second CPTs were lower than the temperature outside, but the temperature inside the MCC between the two CPTs was $3-4^{\circ} \mathrm{C}$ warmer than the temperature outside the MCC (Figure 4(b)).

The distribution of $\mathrm{H}_{2} \mathrm{O}$ measured by the MLS instrument (Figures 3(d) and 3(f)) shows a low concentration of $\mathrm{H}_{2} \mathrm{O}(<2 \mathrm{ppmv})$ at the cloud top at $100 \mathrm{hPa}$ and a high concentration of $\mathrm{H}_{2} \mathrm{O}(>6 \mathrm{ppmv})$ at $68 \mathrm{hPa}$ in the MCC. The distribution of $\mathrm{H}_{2} \mathrm{O}$ is coincident with the temperature distribution because the temperature has a large impact on the concentration of $\mathrm{H}_{2} \mathrm{O}$, especially near the frozen layer. In an environment with a high IWC, the concentration of $\mathrm{H}_{2} \mathrm{O}$ in the upper troposphere and lower stratosphere is directly related to the saturation vapor pressure on the surface of ice crystals. When the temperature increases, the saturation 


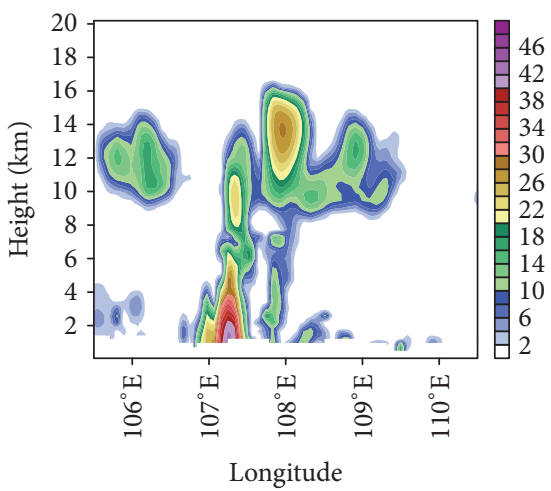

(a) $t=13: 00$

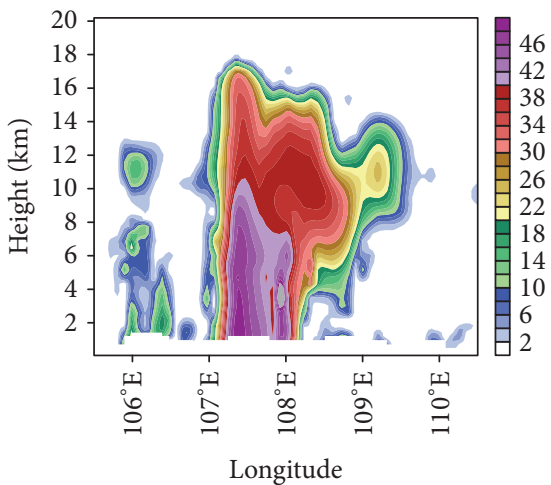

(d) $t=14: 30$

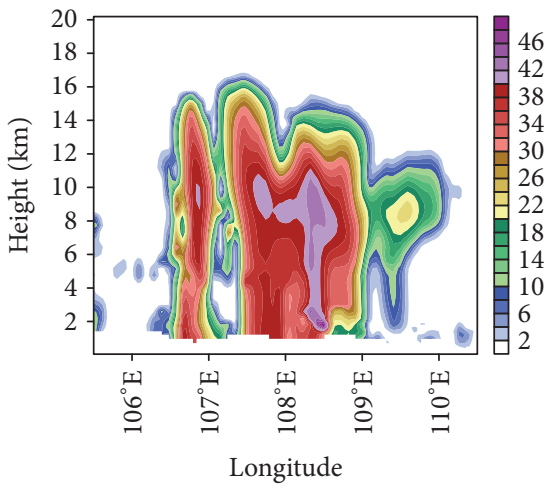

(g) $t=16: 00$

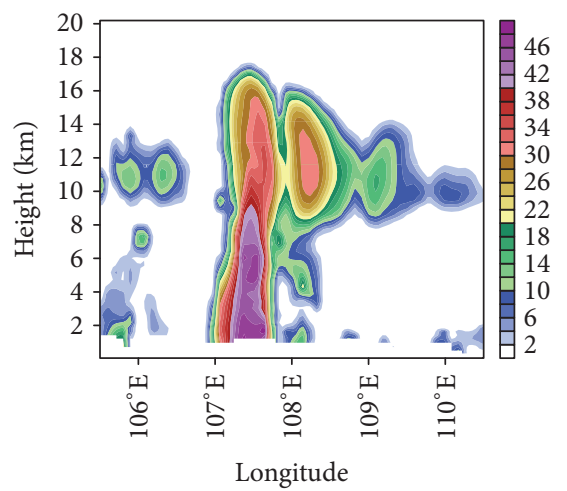

(b) $t=13: 30$

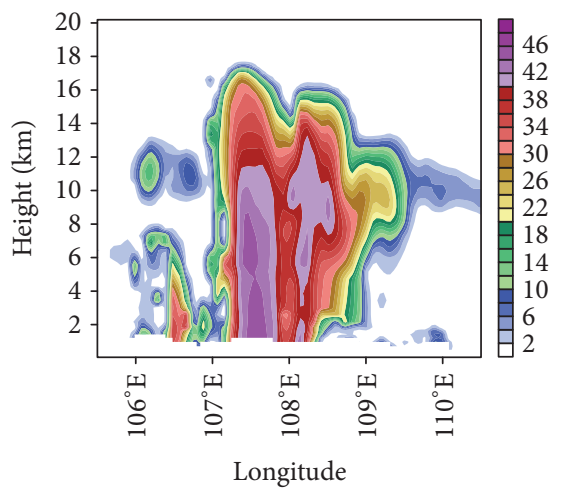

(e) $t=15: 00$

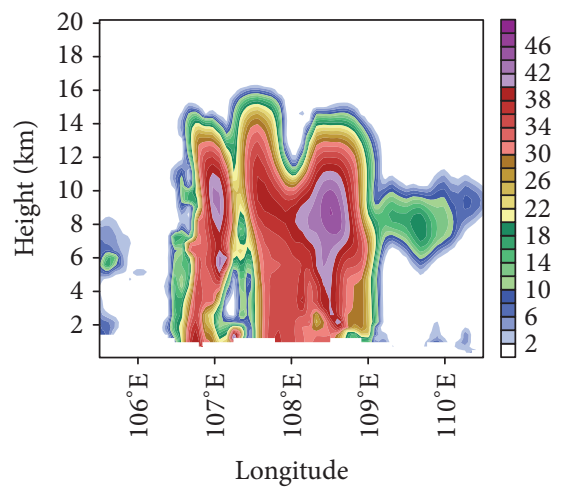

(h) $t=16: 30$

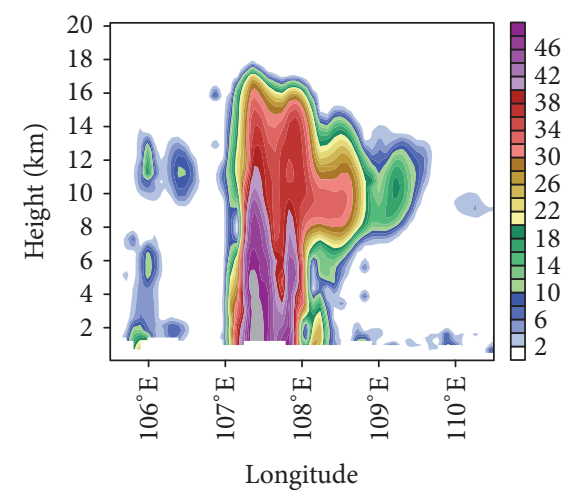

(c) $t=14: 00$

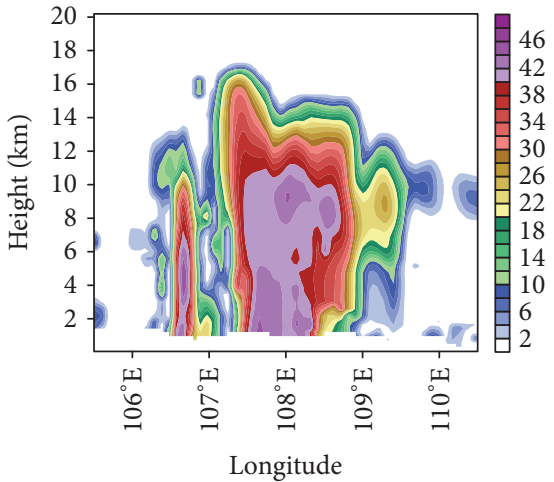

(f) $t=15: 30$

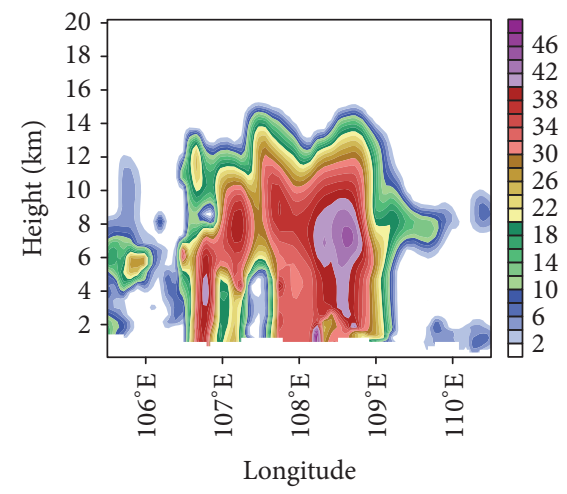

(i) $t=17: 00$

FIgURE 5: Zonal cross-section of the evolution of reflectivity (unit: $\mathrm{dBz}$ ) along $25.4^{\circ} \mathrm{N}$ from the WRF simulations.

vapor pressure also increases and the concentration of water vapor increases as a result of evaporation. Hence the distribution of $\mathrm{H}_{2} \mathrm{O}$ followed the temperature distribution.

\subsection{Upper Troposphere and Lower Stratosphere Atmospheric} Structure in the MCC from WRF Simulations. The positions and heights of the MCC were well simulated by the WRF simulations (Figures 2 and 5). The convective system began to develop at 13:00, the cloud top of MCC reached $17 \mathrm{~km}$ after 14:00, and the MCC matured at about 15:00, slightly ahead of the satellite detection.

The atmospheric structure of the MCC (e.g., the temperature, IWC, and $\mathrm{H}_{2} \mathrm{O}$ distribution) were well represented in the model output. The model output was a good match for the observed divergence, vertical velocity, and potential pseudo equivalent temperature. Upwelling was $-0.8 \mathrm{~Pa} \cdot \mathrm{s}^{-1}$ near $200 \mathrm{hPa}$ in the mature stage of the MCC (Figure 6(a)). There was a strong divergence center $\left(>3 \times 10^{-3} \mathrm{~s}^{-1}\right)$ corresponding to a cold meridional deviation center $\left(-5^{\circ} \mathrm{C}\right)$ at the top of the upwelling region in the MCC near $100 \mathrm{hPa}$. The model showed a disturbance structure for temperature with a negative meridional deviation anomaly of $-5^{\circ} \mathrm{C}$ at the first CPT and $-2^{\circ} \mathrm{C}$ at the second CPT and a positive meridional deviation anomaly of $3^{\circ} \mathrm{C}$ between the two CPTs in the mature stage relative to that in the early stage (Figures 6(a) and 6(b)), which agrees with the GPS radio occultation results shown in Figure 4(b). The temperature anomaly is associated with gravity wave activity and longwave radiation near the cirrus 


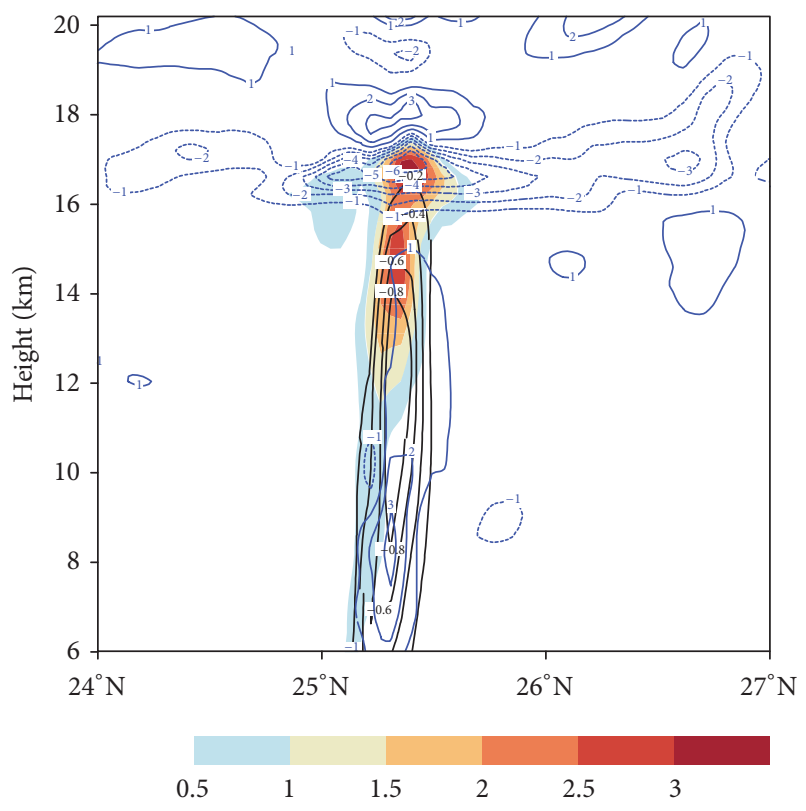

(a)

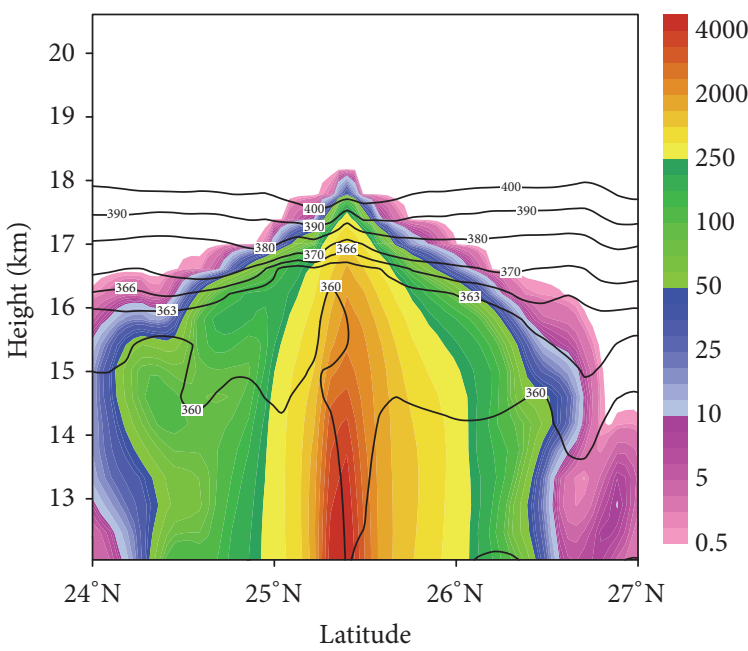

(c)

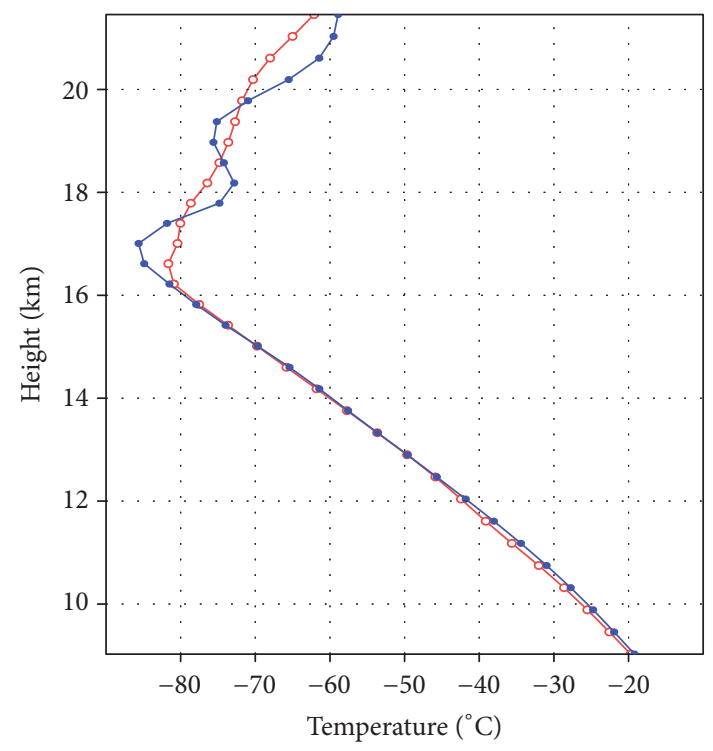

(b)

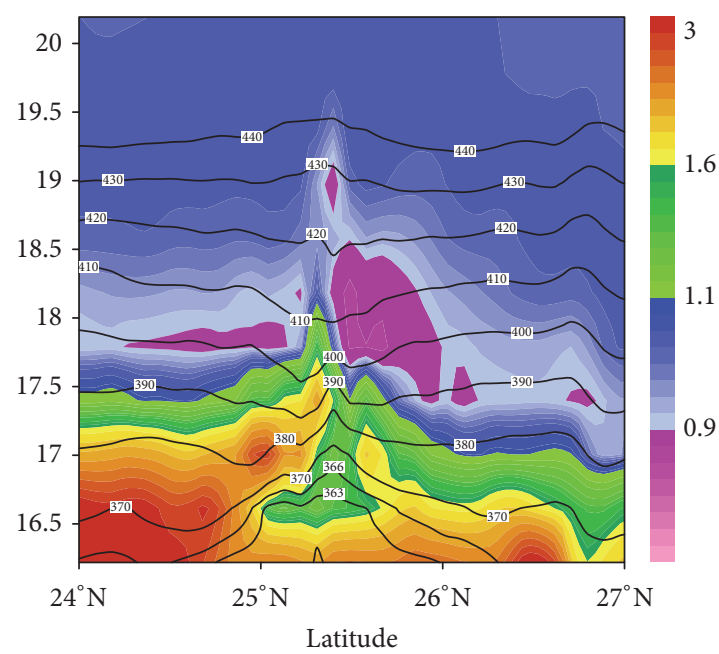

(d)

FIGURE 6: Meridional cross-sections along $107.3^{\circ} \mathrm{E}$ in the mature stage of the MCC from the WRF simulations. (a) Divergence (10 ${ }^{-3} \mathrm{~s}^{-1}$, shading), vertical velocity ( $\mathrm{Pa} \cdot \mathrm{s}^{-1}$, black contours), and meridional temperature deviation $\left({ }^{\circ} \mathrm{C}\right.$, blue contours). (b) Temperature profiles at the mature (blue curves) and early (red curves) stages of the MCC. (c) Total IWC (mg. $\mathrm{kg}^{-1}$, shading) and potential pseudo equivalent temperature ( $\mathrm{K}$, black contours). (d) Water vapor content ( $\mathrm{mg} \cdot \mathrm{kg}^{-1}$, shading) and potential pseudo equivalent temperature (K, black contours).

anvil at the top of the MCC $[27,28]$. Air with a total IWC of $250 \mathrm{mg} \cdot \mathrm{kg}^{-1}$ reached $17 \mathrm{~km}$ (Figure 6(c)), which is consistent with the satellite observations in Figure 3(b). In addition to the temperature disturbance in the upper troposphere and lower stratosphere, there were two lower $\mathrm{H}_{2} \mathrm{O}$ concentrations inside the MCC than outside near $17 \mathrm{~km}$ and $19 \mathrm{~km}$ and a higher $\mathrm{H}_{2} \mathrm{O}$ content inside the MCC than outside near $18 \mathrm{~km}$ (Figure 6(d)).

\section{Conclusions and Discussions}

A variety of satellite observations and WRF simulations were used to study the upper tropospheric and lower stratospheric composition and thermal structure of an MCC that occurred over southern China on 8 June 2009.

The WRF simulations supported the upper troposphere and lower stratosphere temperature structure obtained via GPS radio occultation measurements and MLS observations. The air was $-5^{\circ} \mathrm{C}$ colder inside the MCC than outside at the first CPT near $17 \mathrm{~km},-2^{\circ} \mathrm{C}$ colder inside the MCC than outside at the second $\mathrm{CPT}$, and $3^{\circ} \mathrm{C}$ warmer inside the MCC than outside between the two CPTs. There was a lower water vapor concentration inside the MCC than outside near $17 \mathrm{~km}$ and a higher water vapor concentration inside the MCC than outside near $18 \mathrm{~km}$, corresponding to the temperature structure. This is because the water vapor distribution is 
controlled by the temperature distribution via microphysical processes when a large number of ice crystals are delivered into the upper troposphere and lower stratosphere by the MCC. The ozone-poor air in the upper troposphere and lower stratosphere reflected the convective transport of the MCC.

This study presented the fine structure of the upper troposphere and lower stratosphere in a penetrating MCC during Asia summer monsoon which was rarely reported. Due to the more larger scale of MCC than a common convective activity, the second CPT was located in a higher position than the background climatological CPT, while the location of the second CPT in common convective activity is near the background climatological CPT [10].

\section{Conflicts of Interest}

The authors declare no conflicts of interest.

\section{Acknowledgments}

This study was jointly supported by National Science Foundation of China (41375047, 91537213, and 41675039) and Priority Academic Program Development of Jiangsu Higher Education Institutions (PAPD). The authors would like to thank NASA, UCAR/COSMIC, and National Satellite Meteorological Centre of China for data providing.

\section{References}

[1] C. R. Homeyer, L. L. Pan, S. W. Dorsi et al., "Convective transport of water vapor into the lower stratosphere observed during double-tropopause events," Journal of Geophysical Research: Atmospheres, vol. 119, no. 18, pp. 10,941-10,958, 2014.

[2] L. L. Pan, C. R. Homeyer, S. Honomichl et al., "Thunderstorms enhance tropospheric ozone by wrapping and shedding stratospheric air," Geophysical Research Letters, vol. 41, no. 22, pp. 7785-7790, 2015.

[3] W. Frey, R. Schofield, P. Hoor et al., "The impact of overshooting deep convection on local transport and mixing in the tropical upper troposphere/lower stratosphere (UTLS)," Atmospheric Chemistry and Physics, vol. 15, no. 11, pp. 6467-6486, 2015.

[4] D. Li and J. Bian, "Observation of a summer tropopause fold by ozonesonde at Changchun, China: Comparison with reanalysis and model simulation," Advances in Atmospheric Sciences, vol. 32, no. 10, pp. 1354-1364, 2015.

[5] J. Liu, J. A. Logan, L. T. Murray, H. C. Pumphrey, M. J. Schwartz, and I. A. Megretskaia, "Transport analysis and source attribution of seasonal and interannual variability of CO in the tropical upper troposphere and lower stratosphere," Atmospheric Chemistry and Physics, vol. 13, no. 1, pp. 129-146, 2013.

[6] C. Wang, W. Tian, J. Zhang et al., "Model study of the impacts of emissions, chemical and dynamical processes on the CO variability in the tropical upper troposphere and lower stratosphere," Tellus B: Chemical and Physical Meteorology, vol. 67, no. 1, article 27475, 2015.

[7] A. Gettelman and P. M. D. F. Forster, "A climatology of the tropical tropopause layer," Journal of the Meteorological Society of Japan, vol. 80, no. 4, pp. 911-924, 2002.
[8] J. R. Holton, P. H. Haynes, M. E. McIntyre, A. R. Douglass, R. B. Rood, and L. Pfister, "Stratosphere-troposphere exchange," Reviews of Geophysics, vol. 33, no. 4, pp. 403-439, 1995.

[9] R. Biondi, T. Neubert, S. Syndergaard, and J. Nielsen, "Measurements of the upper troposphere and lower stratosphere during tropical cyclones using the GPS radio occultation technique," Advances in Space Research, vol. 47, no. 2, pp. 348-355, 2011.

[10] R. Biondi, W. J. Randel, S.-P. Ho, T. Neubert, and S. Syndergaard, "Thermal structure of intense convective clouds derived from GPS radio occultations," Atmospheric Chemistry and Physics, vol. 12, no. 12, pp. 5309-5318, 2012.

[11] A. E. Dessler, "Clouds and water vapor in the Northern Hemisphere summertime stratosphere," Journal of Geophysical Research: Atmospheres, vol. 114, 2009.

[12] C. Shi, H. Li, and B. Zheng, "Stratosphere-troposphere exchange corresponding to a deep convection in warm sector and abnormal subtropical front induced by a cutoff low over East Asia," Chinese Journal of Geophysics, vol. 57, pp. 21-30, 2014.

[13] D. Li, J. Bian, and Q. Fan, "A deep stratospheric intrusion associated with an intense cut-off low event over East Asia," Science China Earth Sciences, vol. 58, no. 1, pp. 116-128, 2015.

[14] D. Chen, D. Lü, and Z. Chen, "Simulation of the stratospheretroposphere exchange process in a typical cold vortex over Northeast China," Science China Earth Sciences, vol. 57, no. 7, pp. 1452-1463, 2014.

[15] D. Hu, W. Tian, F. Xie, C. Wang, and J. Zhang, "Impacts of stratospheric ozone depletion and recovery on wave propagation in the boreal winter stratosphere," Journal of Geophysical Research: Atmospheres, vol. 120, no. 16, pp. 8299-8317, 2015.

[16] D. Guo, Y. Su, C. Shi, J. Xu, and A. M. Powell, "Double core of ozone valley over the Tibetan Plateau and its possible mechanisms," Journal of Atmospheric and Solar-Terrestrial Physics, vol. 130-131, no. 8, pp. 127-131, 2015.

[17] D. Hu, W. Tian, Z. Guan, Y. Guo, and S. Dhomse, "Longitudinal asymmetric trends of tropical cold-point tropopause temperature and their link to strengthened walker circulation," Journal of Climate, vol. 29, no. 21, pp. 7755-7771, 2016.

[18] B. H. Kahn, F. W. Irion, V. T. Dang et al., "The Atmospheric Infrared Sounder version 6 cloud products," Atmospheric Chemistry and Physics, vol. 14, no. 1, pp. 399-426, 2014.

[19] N. J. Livesey, W. G. Read, and P. A. Wagner, Earth Observing System (EOS) Aura Microwave Limb Sounder (MLS) Version $4.2 x$ Level 2 Data Quality And Description Document, Jet Propulsion Laboratory, California Institute of Technology, 2015.

[20] G. L. Stephens, D. G. Vane, R. J. Boain et al., “The cloudsat mission and the A-Train: A new dimension of space-based observations of clouds and precipitation," Bulletin of the American Meteorological Society, vol. 83, no. 12, pp. 1771-1742, 2002.

[21] K. Sassen, Z. Wang, and D. Liu, "Global distribution of cirrus clouds from cloudsat/cloud-aerosol lidar and infrared pathfinder satellite observations (CALIPSO) measurements," Journal of Geophysical Research: Atmospheres, vol. 113, no. D8, 2009.

[22] D. J. Posselt, G. L. Stephens, and M. Miller, "CLOUDSAT: Adding a new dimension to a classical view of extratropical cyclones," Bulletin of the American Meteorological Society, vol. 89, no. 5, pp. 599-609, 2008.

[23] Z. Y. Fang and D. Y. Qin, "A review of satellite observed heavy rainfall cloud clusters," Journal of Applied Meteorological Science, vol. 17, pp. 583-593, 2006 (Chinese). 
[24] R. A. Anthes, P. A. Bernhardt, Y. Chen et al., "The COSMIC/ Formosat-3 mission: early results," Bulletin of the American Meteorological Society, vol. 89, no. 3, pp. 313-333, 2008.

[25] R. A. Maddox, "Mesoscale convective complexes," Bulletin of the American Meteorological Society, vol. 61, no. 11, pp. 1374-1387, 1980.

[26] L. L. Pan and L. A. Munchak, "Relationship of cloud top to the tropopause and jet structure from CALIPSO data," Journal of Geophysical Research: Atmospheres, vol. 116, no. 12, article D12201, 2011.

[27] E. F. Danielsen, "A dehydration mechanism for the stratosphere," Geophysical Research Letters, vol. 9, no. 6, pp. 605-608, 1982.

[28] J. P. Chaboureau, J. P. Cammas, J. Duron et al., "A numerical study of tropical cross-tropopause transport by convective overshoots during the TROCCINOX golden day," Atmospheric Chemistry \& Physics, vol. 7, no. 7, pp. 1731-1740, 2008. 

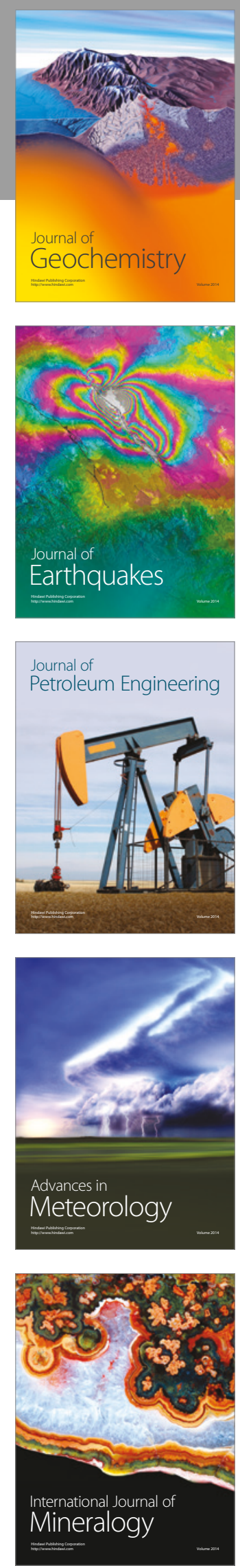
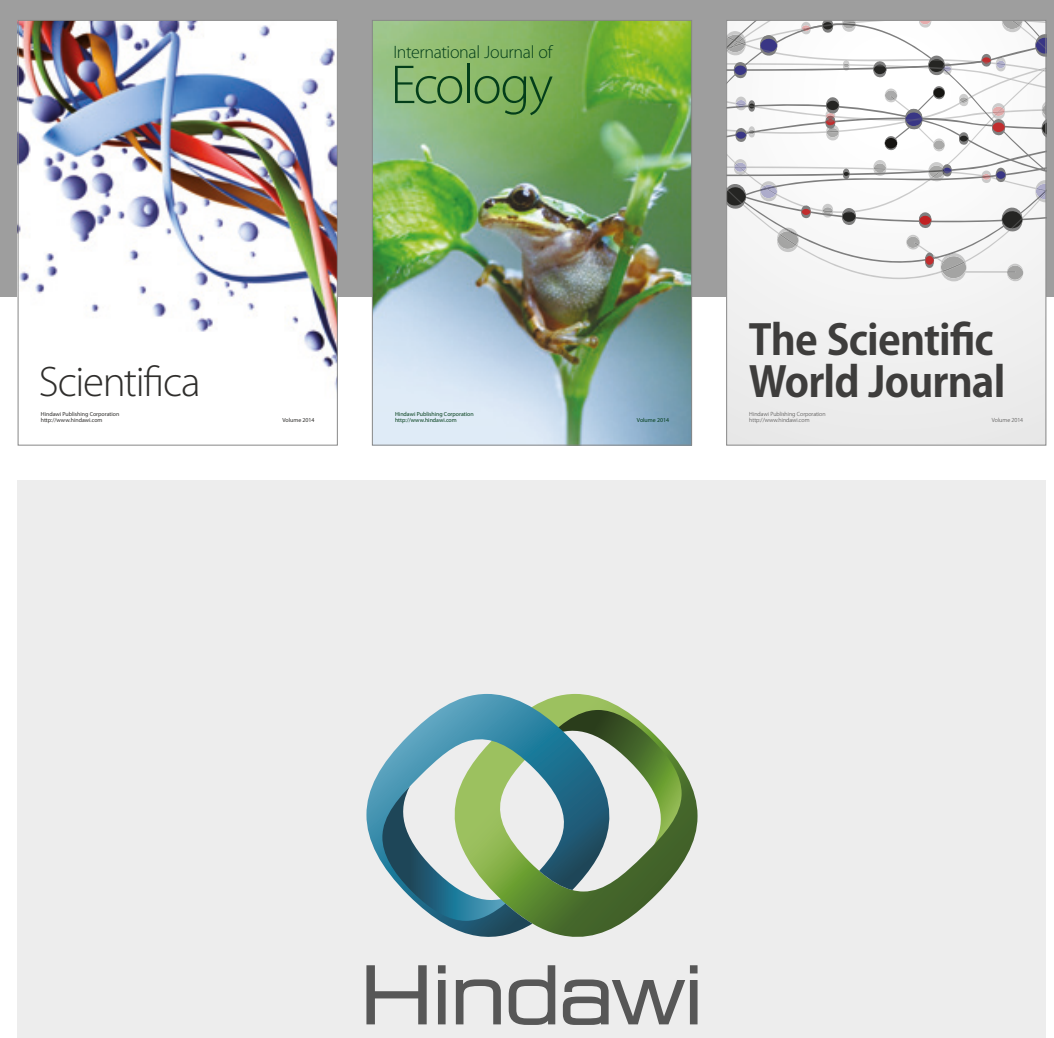

Submit your manuscripts at

https://www.hindawi.com
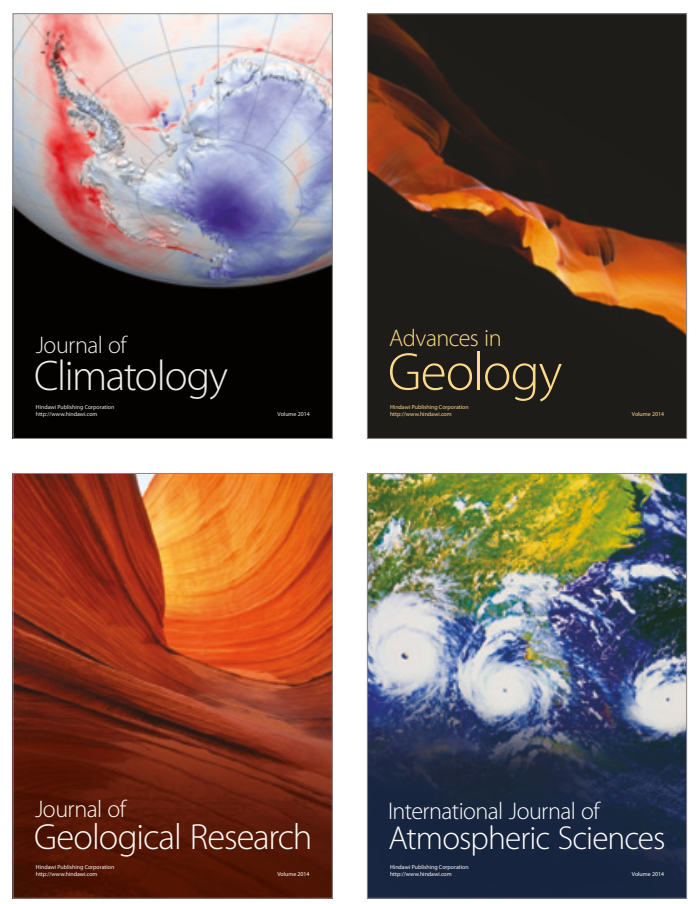

The Scientific

World Journal
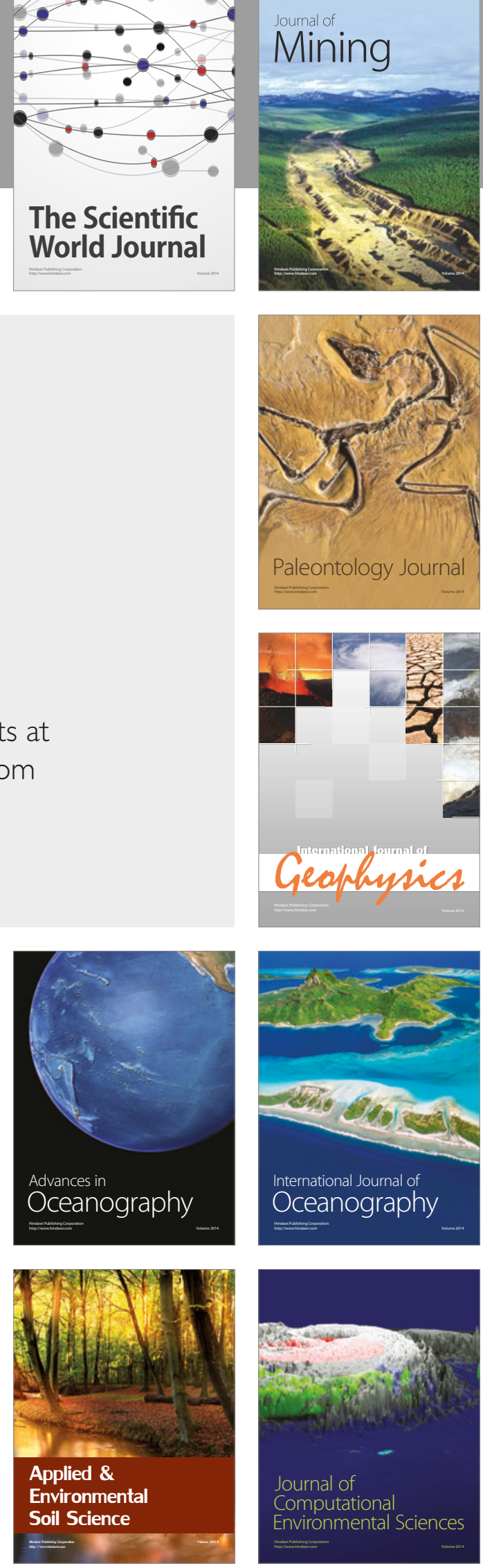